\title{
Role and Importance of Family at Preschool Children Environmental Education
}

\author{
By Seval Güven ${ }^{1}$, Nihan Yilmaz ${ }^{2}$
}

\begin{abstract}
Environmental problems we face recently are not a surprise. These problems are a result of years of unconsciousness. Changing negative, insensitive, unconscious human behaviours; obtaining wanted behaviours and showing empathy toward the environment are possible with just environmental education. If Environmental Education and Consciousness are not taught to the all community and necessary precautions are not taken, environmental problems in twenty first century which we are in will become more and more serious problem. Giving first education in family is very important because this education will become the base of person's life. Parents are the first teachers oftheir children. They are foremost responsible for their children's growth and education until they start school. Parents responsibilities and powers over their children's education could be utilized and extended during preschool education by the help or planned educational activities that require active involvement of parents. This education will help solving the environmental problems we experience and bringing up new generations who live within nature.
\end{abstract}

Keywords: environmental education, family and environment, pre-school period.

\section{Introduction}

To understand the nature of environmental problems, to bring solution proposals and to bring changes in the behaviors of individuals in relation to the environment are only possible with environmental education. It is a known fact that individuals with a certain education and sensitivity play a more active role in solving environmental problems. In order forpeople to be able to live in a healthier and safer environment, it is necessary to provide them with necessary environmental knowledge and skills (Özbuğutu and Karahan, 2014).

Environmental education, can be described as the recognition and distinction of values, attitudes, and concepts related to the biological, physical, and social environment by the individual and the development of environmental consciousness in all segments of the society, bringing environmentally conscious, permanent, and positive behavioral changes, preservation of natural, historical, cultural, socio-aesthetic values, active participation in the subject of environment, and bringing the initiative to take part in problem solving (Önder and Özkan, 2013).

Unfortunately, environmental education is still examined with a fantastic approach and detracted from science programs in our country. However, the multidiscipline and interrogative character it will bring to the science education and its ability to form a democratic participatory and responsible individual are ignored. If we want to create a democratic and interrogative society, we can raise environmental consciousness in children starting from the preschool period. In this context, the diversification of 
environmental education programs by every age and educational level is necessary to increase environmental consciousness.

\section{Environmental Consciousness}

The environment has been continuing its existence since the very creation of the world, the basic living space, up to present. Since the first man up to present, the human being, who had been trying to identify and understand the space he lived in, has been trying to identify this space he lives in. The recognition, identification, and understanding of the environment of individuals, particularly after the industrial revolution, have become intense. Nowadays, the concept of environment has been defined by many scientists and international institutions and organizations. These definitions show what wide content and meaning the concept of environment has (Özbuğutu and Karahan, 2014).

To have environmental consciousness constitutes the framework of contemporary human behaviors that include the principles of equality and justice of basic human rights. The environmental consciousness of modern people requires making efforts to make also the people around them feel the individual responsibility they have in themselves. In the formation of environmental consciousness and awareness, great responsibilities and duties fall to all segments of the society and people of all ages, from the smallest unit of the society, family, to educators and from local governments to citizens (Yazic1-Okuyan and Gedikoğlu, 2012).

Environmental consciousness is;

- The conception of the social, historical, and natural environment of an individual and his/her acquisition of conscious awareness,

- The participation of an individual in the solution of problems faced in relation to the environment through non-governmental organizations,

- An individual's taking initiatives to defend his/her rights and show his/her reaction,

- The conception of the need to use the environment without destroying it,

- The conception of the importance and indispensability of the natural life and natural resources for human life,

- Being interested in and monitoring events realizing in individuals' historical, natural, and social environments and prioritizing the saving in all consumption activities (Keleş, 1997).

Environmental consciousness has intellectual, emotional, and behavioral dimensions. In other words, environmental consciousness consists of thoughts containing environmental decisions, principles, and interpretations, the behaviors that are the transfer of these thoughts to life and various emotions related to all these. The development of environmental consciousness in individuals is closely related to the knowledge of what kind of preliminary knowledge they have about the environment (Türküm, 2006).

Nowadays, it is a fact that we experience important environmental problems even if their cause or source is perceived differently. This problem is not caused by nature itself, but by human behaviors. Therefore, the solution of the problem depends on us changing our ethical understanding that directs our behaviors towards nature and ourselves. In this 
context, the development of environmental consciousness and awareness and the creation of behaviors related to the protection of the environment in individuals can only be achieved through environmental education.

\section{Environmental Education in the Preschool Period}

Environmental problems are among the most remarkable issues nowadays. Factors such as changing living conditions, technological advances, rapid population growth, industrialization, urbanization, etc., increase environmental problems. In this context, raising environmental consciousness is of great importance in the national and international area. Environmental problems and the consequences they have caused have brought the concept of environmental education into the agenda (Atasoy, 2006).

The need for environmental education arises from the request to provide the most favorable conditions for human life. Whether the environment is good or bad is the main purpose of the development of civilization, and it directly affects the health of life, which is the natural right of the humanity. All social problems lose their meaning in case when the natural conditions necessary for the existence and development of an individual are deficient. Therefore, it should not be contented with the inclusion of environmental education in the structure of the education system, and it should be ensured that it constitutes one of the principles of education (Turkiye Environment Foundation, 2007). Researchers state that environmental knowledge and attitude towards the environment begin to take shape in the preschool period and that environmental awareness acquired in the pre-school period also takes an important place in the development of positive attitudes towards the environmentin the future. In fact, the results of various studies aimed at determining the perceptions of preschool children of the environment and environmental problems and their attitudes towards them also support these findings (Lubomira, 2004).

The preschool period is magical years containing critical periods for all development areas, being cognitive, social-emotional, motor, and language development. Most of the attitudes and behaviors gained during this period still exist in adulthood. Therefore, the experiences in this period are very important. One of the most specific characteristics of preschool children is being curious. Therefore, environmental education to be given by monitoring the curiosity of the child in this period is a key for the child to become an environmentalist, respectful to nature, and a sensitive adult (Yayla Ceylan and Ülker, 2014).

The environmental education given to children should be provided in nature, benefiting from the most natural ways. However, nowadays, children, especially in big cities, are growing up away from nature. Due to the fact that very limited safe outdoor areas (parks, playgrounds, urban forests, squares, etc.) are not sufficient as a result of the distorted and unplanned housing in cities, many children spend their time in closed areas and have very little relationship with the society and nature (Başal, 2005). On the other hand, being in touch with nature allows children to use all their senses. Furthermore, children's being in touch with nature in daily life has a great contribution to the environment as well as to the development of children (Handler and Epstein, 2010).

Being outdoors helps children to spend their energy, which allows them to focus more 
calmly on other subjects. Moreover, the innate interest in nature also helps them to focus. Experiences of children in nature increase their intellectual richness and sense of unity (Handler and Epstein, 2010).

Neill (2008) listed the benefits of children's being outdoors as follows:

- Children with attention deficit and hyperactivity disorder symptoms can focus better after they get in touch with nature.

- Children who see nature and meet nature get higher scores in focus and self-discipline tests.

- The body coordination, balance, and agility of children who regularly play in the natural environment are advanced, and these children become sick less frequently.

- When children play in the natural environment, their games become more creative and more diverse. This develops their ability to work together and improve their language skills.

- Being in the natural environment allows children to develop their awareness, interrogation, and observation skills and improve their comprehension skills.

- Nature reduces stress on children and helps them to deal with difficulties.

- Playing in different environments reduces antisocial behaviors such as violence, bullying, and vandalism.

- Nature provides the development of observation and creativity in children and instills the feeling of peace into children gradually.

- There are positive effects of meeting with nature at an early age on the formation of imagination and curiosity. Curiosity is an important source of motivation for life-long learning to continue.

- Children playing in nature have more positive thoughts about each other.

- The decrease in the time that children spend in nature causes an increase in the rate of myopia.

- Nature revitalizes the social relationship between children.

- Being present in nature leads to the independence of children.

As can be seen, there are two basic points on which environmental education is based in the preschool period: the first one is to ensure the communication of the child with the outside world, and the other one is to support the healthy development of the child (Wilson, 1996). In this direction, children who recognize their surroundings and develop sensitivity towards the environment will also be at peace with themselves and will respect themselves and their surroundings (Kocakurt and Güven, 2005).

Wilson (1996) noted the outlines for the environmental education programs to be applied to preschool children as follows:

1. Begin with simple applications. Small children learn best in an environment in which they feel sincere and comfortable. The best place for this is the environment they know. For example, a tree or playground in the backyard must be used before going to a forest or woodland for education.

2. Children should directlyparticipate in education because children learn better with concrete experiences in which they actively participate. A one-time trip to a park or an environment will have little impact on children. It is better to provide children with the environment where they can spend time and energy with grass, trees, and insects near their house. 
3. Experiences must befocused on rather than education because children learn by discovering and doing things themselves. Here, adults should play a helpful role than the role of an educator. Instead of the "watch and listen" education method, more than one educational method in which children are actively involved should be used.

4. Educators should demonstrate their pleasure and interest in nature to children by applying them. The demonstration of this issue is important for the success of environmental education. Addressing children's emotions in the instillation of the love of nature to children is much more important than facts.

5. Environmental education should be modeled, and the environment should be respected. It is much more effective to showinterest in the world and environmentinsimple practical forms than to talk to children about it. The interest and respect for the environment can be demonstrated by taking care of the surrounding plants and animals, establishing or preserving the natural environment in which animals and plants are found in house gardens, collecting and throwing away the garbage properly, and contributing as much as possible to recycling.

Due to the reasons generally mentioned above, it has become a necessity for environmental education to take place systematically in the educational stages starting from preschool education. The introduction of the preschool environmental education in the existing national education is important in terms of guiding the environmental education practices.

\section{The Role and Importance of the Family in Environmental Education}

Nowadays, when the environment has become an important issue of the humanity, it has become an inevitable necessity for our children, who are the inheritors of the world, to be informed and conscious about the environment in particular (Atasoy, 2006).

Children are the group most affected by the physical, biological and social environment. The current and future effects of the environment are more prevalent in children because their lives and development depend on it. Our children, the elders of tomorrow, will play an active role in ensuring the development of the society and a sustainable life, with their knowledge, skills, values, experiences, and behaviors. Especially nowadays people are raising the level of production and consumption by using natural resources indifferently for the sake of increasing the level of welfare and further development, at the cost of the deterioration of ecological balance. For this reason, it has become more important than ever before to educate children who consume by considering the environment kaynak

As a matter of fact, it has been revealed in the studies conducted that children who recognize their environment in their first years of life and who are sensitive and protective to their surroundings continue their attitudes in the following years (GülayOgelman and Güngör, 2015).

In this context, the environmental education to be provided to small children will help them to increase their consciousness of the environment in addition to helping them to recognize the environment (Gulay, 2010).

The environmental education to be given to children can have two goals: the first one is 
to provide social and cultural accumulation. The second one is to give information about the environment, environmental problems, solution of the problems, and especially the areas for which children are responsible (Büyüktaşkapu and others, 2011).

Raising, directing, and illuminating individuals, who are environmentally conscious, have freedom of thought, and self-determinedare realized in the family where a child receiveshis/her first education. The reason why the most important duty in the socialization of a child belongs to the family is that the social relationship of a child is with the family members in his/her very critical first years of life (Güven, 2011).

A family member is the most basic component that forms the basis of the feelings and ideas related to the human life and experiences. Since the first socializing institution of an individual is the family, the family is the first and basic influence in the formation of attitudes. Some attitudes have the property of being permanent since the family is the institution where intense emotional relationships are experienced (Malik, 2004). Which objects have apositive attitude, which objects have a negative attitude are given to individuals in the family through socialization. The values and culture of the society are also transmitted to the individual in the family. The values that are valid in the family reflect the values of the society in which they live (Zorlu, 2006). Decisions takenamong the members of the family also determine the society in which family members are consumers and the consumption trends of this society (Bayraktar, 1989).

Among the tools of socialization enabling the child to learn consumerism, the family is the best means of teaching, and the attitudes and behaviors gained in the family continue their effects in adulthood (Fan and Li, 2010). For small children, the environment is the whole surrounding in which they are; for example, their room, house, family, family, neighbors, the garden, if any, street, etc.

Children learn what is happening in their surroundings primarily through communication with their parents. For this reason, home education sets out the seeds of children's behavior and moral shaping in the future (Haktanır, 2007). It is one of the first duties of parents to tell children that they are the members of an organized group having its own rules and that they have to do their duties to benefit from their rights beginning from the first years of the child. One of the basic parenting duties that the family has to fulfill is to ensure that children learn about their surroundings, lives, and principles in this environment.

In the first years of life, things that children will learn about the environment are divided into 2 as follows:

- Getting to know the environment

- Protecting the environment (Domka, 2004).

The right message to give to the child when he/she recognizes the environment is that these objects, individuals, that is, the environment itself, belong to them and they are a part of this environment. For example, "your room", "our school", "our family", "our apartment". Thus, the concept and feeling of embracing the environment and belonging to the environment will develop in the child. The next step is to add the sense of responsibility to embracement. If the child feels responsible for his/her environment at a younger age, he/she tends towards environmental protection behaviors. The environmental protection behaviors are behaviors such as child's collecting toys scattered 
by him/her, keeping his/her room in order, not dirtying the house, helping to collect materialsand put them into their places after an activity in the kindergarten. Bringing these behaviors to the child at home within the family is realized firstly through being an example because the small child is both an observer and an imitator (Haktanir, 2007; Gülay and Ekici, 2010; Güven, 2001).

The correct message that should be given to the child when he/she identifies the environment is that this environment belongs to him/her and that he/she is a part of this environment. Thus, the concept of accepting the environment and feeling of belonging to the environment will develop in the child. The next step is the adoption of the sense of responsibility. If the child feels a sense of responsibility towards his/her environment at a younger age, he/she will tend towards environmental protection behaviors. Parents can emphasize the importance of keeping the home environment clean, tidy, and healthy by telling and applying it to their children (including theregular gathering of things, toys, not dirtying the house, regular collectionand throwing of garbage, etc.)and can provide them with environmental protection behaviors.

Parents can make lives with their children pleasurable and turn them into an environment lesson with trips and environmental protection behaviors they apply in their family life. Activities such as going out on a trip to rural areas, going to a zoo, going to a park or a museum, participation in trips, going on a vacation, planting a flower or a tree in the garden, and shopping together are both enjoyable and important in terms of informing children about the nature and environmental pollution (Handler and Epstein, 2010). We can instillthe love of nature into them by telling them about the indispensableimportance of each new plant and animal species for our lives, that all of the things we consume come from nature, and that one day they will come and go. We can become an example to them of how we can live without polluting the environment, especially with conscious environmental protection behaviors that we will apply in our home and family life because children are both observers and imitators. They shape their behaviors by modeling the knowledge and behaviors they learn from their parents (Güven, 2001; Haktanır, 2007).

Furthermore, one of the most important steps that parents should take in order toprovide their children with environmental protection behaviors is to teach them to avoid wastefulness as much as possible.

Hundreds of simple and everyday tasks such as;

- Burning the light in the required areas for less electricity consumption,

- Preventing the excessive paper consumption,

- Not draining water unnecessarily (turning off the tap when brushing teeth, taking a short shower),

- Turning off the radio and television that are not being listened to,

- Applying for isolation measures to consume less heat energy,

- Collecting glass, paper, and plastics separately in the garbage, etc.

can create some examples of behavior in which children can save significant amounts of water and energy consumption in the future (Rogers, Kostigen, 2008; Prokop,1994).

Apart from these measures that can be taken for the protection of the environment, important responsibilities also fall to families in the socialization of children as conscious consumers (Gökçek, 1997). Parents teach their children to buy quality and 
environmentally friendly products and price-quality relationships with their experiences in using themoney. While the knowledge and skills learned in the family environment will affect the future adult behaviors of children, the future consumption behaviors of children will largely be determined by their parents' consumption behaviors (Özgen, 1995). In this context, families' being conscious of the existence of resources in the environment, the cost of use, the effect of the use on the family, and the effect of the consumption costs of the family on the environment in their decisions, and exhibiting an environmentalist approach to the evaluation of shopping and utilization of wastes will be reflected directly in children's behaviors in a positive way (Güven, 2001).

Environmental education should not be limited onlyto giving information and bringing responsibility but should also make changes in the behavior. Great duties fall to families in protecting the natural and manmade environment, attracting interest and attention to environmental problems, bringing knowledge and teaching behaviors for the solution of problems, teaching the preservation of history and cultural heritage, and adopting love and respect for nature (Nazlıoğlu, 1993).

Studies express the benefits of the participation of families (mother, father) in the following way. It will increase communication between parents and children and make them more qualified. Parents will be educated about the environment, and their awareness will be increased. Environmental education programs can be evaluated in a versatile way. Parents will reinforce the introduction and endearment of the environment and creation of the environmental consciousness as in teaching all subjects and concepts. For this reason, preschool educators should inform parents with their family involvement studies and make the continuity of the education process a provider (Gülay and Öznacar, 2010). For all these reasons, since the knowledge and skills, environmental awareness, and values necessary for a better life represent the future of people, they should be transferred especially to children and mothers in the family. Compared to fathers, mothers spend more time together with children and are more intimately connected with them. Therefore, their education has an important place inraising theenvironmental consciousness of children. This demonstrates the importance of the literacy for female children and women and receiving environmental education. Providing lifelong education in ensuring the sustainable development starting from childhood, will play an important role in the development of the society and the protection of the environment by ensuring that conscious individuals are raised in this respect (Güven, 2010).

\section{Discussion and Conclusion}

Families and educational institutions have important duties in introducing theenvironmentto children, making them love it, raising awareness, and sensitivity towards environmental protection (Gülay and Öznacar, 2010).

Children's recognition of nature normally begins with being found in nature. They know and learn nature by taking pleasure in playing alone or with a group of children (Handler and Epstein, 2010). Environmental issues should be included in education during early childhood so that children develop positive attitudes towards the environment at an early age (Russo, 2001). 
Since small children learn nature by being in touch with nature, parents should pay attention to nature, the quality of child-nature relationships, and the frequency of this relationship. Unfortunately, most young children do not have these opportunities; they are limited (Wilson, 1996). Natural events, growing up by being in touch with nature, environmental education in nature and more make it easier for children to acquire new information. The task of families is to monitor children and help them to understand their experiences, learn about nature, respect nature, and have fun (Dowling, 2010).

The world is gradually deteriorating through human influences. For this reason, there is a need for young generations to find solutions to ecological problems. In order to raise generations who are sensitive to environmental problems and haveenvironmental consciousness, it is necessary to teach our children to protect the existence of the ecological system and how to live in harmony with the system and its methods (Önder and Özkan, 2013).

Although environmental issues are indirectly addressed in primary education programs within different lessons, starting environmental education with the family in the preschool period will increase achievements of children in environmental issues. In order forfamilies to give environmental educationto children, awareness should be raised of the importance of this education and its roles in education through widespread and formal education.

\section{References}

Anon, S. (1994). Tüketici Kararlar ve Cevre. Ankara: TSE Yayınları.

Ağyar, E. (2014). Küçük Çocuklara Çevre Eğitimi Neden Önemlidir? H. Gülay Ogelman içinde, Cocuk ve Cevre, Küçük Cocuklar ve Çevre Eğitimi El Kitabı (s. 111-125). Ankara: Eğiten Kitap.

Atasoy, E. (2006). Cevre İ̧̧in Ĕğtim. Çocuk doğa Etkileşim. Bursa: Doğa Kitabevi.

Başal, H. (2005). Okul öncesi Eğitiminde Uygulamal Çevre Ë̆itimi. Erken cocuklukta gelişim 4. ve eğitimde yeni yaklassimlar 2. İstanbul: Morpa Kültür Yayınları.

Bayraktar, M. (1989). Tüketici Kararlar ve Cevre. Standart ekonomik ve Dergi, 28(334), 5.

Buhan, B. (2006). Okul Öncesinde Görev Yapan Ögretmenlerin Çevre Bilinci ve Bu Okullardaki Cevre Ĕ̈itiminin Araștırlması. Yayımlanmamış Yüksek Lisans Tezi. Marmara Üniversitesi, Eğitim Bilimleri Enstitüsü, İstanbul.

Büyüktaşkapu, S., Koçyiğit, S., Öztürk-Samur, A. ve Özenoğlu-Kiremit, H. (2011). Çocuk ve Çevre. Ankara: Vize Yayıncilik.

Cohen, S., Horm-Wingerd, D. (1993) Children And Envionment. Ecological Awareness Among Preschool Children. Environment and Behavior, 25 (1), 1033-120.

Domka, L. (2004). Environmental Education At Pre-School. International Research in Geographical And Environmental Education, 13(3), 258-263.

Dowling, J. (2010). Preschoolers And Nature - Snag As A Bug İn A Rug. Highscope Extensions.

Fan, Y. And Li, Y. (2010). Children's Buying Behaviour İn China: A Study of Their Information Sources. Marketing Intelligence and Planning. 28(2), Pp. 170-187.

Geçmiş, H. H., Salı, G. (2014). Çevre Eğitimi Neden Önemlidir? Küçük Çocuklar ve Çevre Eğitimi El Kitabı. Ankara: Eğiten Kitap.

Gökçek, T. (1997). Tüketim ve Çevre Bilinci. Tüketici Bülteni, 10(113), 4.

Gülay, H., Önder, A. (2011). Sürdürülebilir Gelişsim İ̧cin Okul Öncesi Dönemde Çevre Eğitimi. Ankara: Nobel Yayın Dağıtım.

Gülay, H., Ve Ekici, G. (2010). MEB Okul Öncesi Eğitim Programının Çevre Eğitimi Açısından Analizi. Türk Fen Ë̆gitimi Dergisi, 7 (1), 74-84.

Gülay, H., Duran Öznacar, M. (2010). Okul Öncesi Çevre Etkinlikleri. Ankara: Pegem Akademi. 
Gülay-Ogelman, H., Güngör, H. (2015). Türkiye'deki Okul Öncesi Dönem Çevre Eğitimi Çalışmalarının İncelenmesi: 2000-2014 Yillar1 Arasındaki Tezlerin ve Makalelerin İncelenmesi. Mustafa Kemal Üniversitesi Sosyal Bilimler Enstitüsü Dergisi, 12(32), 180-194.

Gürkaynak, İ. (1993). Kadın-Aile, Cevre. Ankara: Ankara Üniversitesi Basımevi.

Güven, S. (2001). Çocuk, Aile ve Çevre. Coluk Cocuk Dergisi, 3,3

Güven, S. (2010). Sürdürülebilir Kalkınma Açssndan Aile, Tüketim ve Cevre. Tüketici Yazıları II. Ankara: Comart Kurumsal İletişim Hizmeti.

Handler, D., Epstein, A. (2010). Nature Education İn Preschool. Highscope Extensions(25), 1-7.

Haktanır, G. (2007). Okul Öncesi Dönemde Çevre Eğitimi. Çevre Eğitimi. Türkiye Cevre Vakfı Yaymı No: 178, Ankara, 11-34.

Ilgar, R. (2007). Çevre Eğitiminde Yaygın Eğitimin Rolü Ve Önemi. Ondokuz Mayıs Üniversitesi Eğitim Fakültesi Dergisi, 23, 38-50.

Keleş, R. (1997). Cevre, Yurttass, Sorumluluk. İstanbul: İmge Kitapevi.

Kilıç,S. (2008), Cevre Etiği. Ankara : Orion Kitapevi Yarg1 Yayınevi.

Kocakurt, Ö., Güven, S. (2005). Çevre, Aile Ve Çocuk. Eg̈itim ve Bilim, 30(135), 34-38.

Malik, K. (2004). Family and Sustainable Development. (Retrieved Date: 13.05.2017) http://www.undp.org

Malkus, A. J., Mussler (1994) The Children's Attitudes Toward the Environment Scale. The Journal of Environmental Education, 25 (3), 22-26.

Malkus, A. J., Mussler (1997). Environmental Concern in School Age Childen. Paper Presental at the Biennial Meeting of The Society for Research in Child Development. Washington DC, 221-223.

Nazlıŏlu, M. (1991). Sürdürülebilir Kalkınma Açısından Kadın Ve Çevre. Sürdürülebilir Kalkınma El Kitabı. Ankara: Türkiye Çevre Sorunları Vakfi.

Neill, P. (2008). Real Science in Preschool: Here, There, And Everywhere. Highscope Press.

Özkan, B. (2013). Sürdürülebilir Cocuk Gelişimi. Ankara: Anı Yayıncılık.

Özgen, Ö. (19959. Tüketicinin Sosyalleşmesine Yaşam Dönemi Yaklaşımı. Standart, 34 (402), 85-91.

Özbuğutu, E., Karahan, S. (2014). Çevre Eğitimi ve Alternatif Yöntemler. Mustafa Kemal Üniversitesi Sosyal Bilimler Enstitüsü Dergisi, 11 (25), 393-408.

Prokop,M.K. (1994). Yessil Yönetim, Ankara:Önder Matbaa.

Rogers,E., Kostigen,M.T. (2008). Yeşil Kitap. İstanbul:Butik Yayınları

Russo, S. (2001). Promoting Attitudes Towards Environmental Education Depends On Early Childhood Education. Primary And Junior Science Journal, 34-36.

Smith, A. (2001) Early Childhood- A Wonderful Time for Science Learning. Australian Primary \& Junior Journal, 17 (2), 52-55.

Taşkın, Ö., Şahin, B. (2008). "Çevre” Kavramı ve Altı Yaş Okul Öncesi Çocuklar. Pamukkeale Üniversitesi Ë̈itim Fakïltesi Dergisi(23), 1-12.

Türkiye Çevre Vakfi. Türkiye'de Cevre Eğitimi. Ankara: Önder Matbaa.

Türküm, A. S. (2006). Cağdas Toplumda Cevre Sorunlar ve Cevre Bilinci. (Retrieved Date: 11.04.2017). http://w2.anadolu.edu.tr/aos/kitap/1oltp/1268/unite10.pdf

Ural, S. (1991). Okulöncesi Dönemde Cevre İ̧̧in Eğitim-Çevre Eğitimi. Ankara: TüRkiye Çevre Eğitimi Vakfi.

Wilson, R. A. (1996) Environmental Education Programmes For Preschool Childen. Journal Of Enviromental Education. 27 (04), 71-81

Wilson, R. A. (1996). Starting Early: Environmental Education During The Early Childhood Years. ERIC Clearinghouse For Science Mathematics And Environmental Education Columbus $\mathrm{OH}$.

Yayla-Ceylan, Ş., Ülker, P. (2014). Okul Öncesi Dönem Çocuklarında Çevre Eğitimi Neden Önemlidir? H. Gülay Ogelman İçinde, Çocuk ve Çevre, Küçük Çocuklar Ve Çevre Eğitimi El Kitabı (S. 37-58). Ankara: Eğiten Kitap.

Yazıcı-Okuyan, H., Ve Gedikoğlu, Y. (2012). Aytül Akal'ın Çocuk Kitaplarında Çevre Bilinci ve Duyarlığı. Turkish Studies - International Periodical For The Languages, Literature And History Of Turkish Or Turkic, 7(2), 793-806.

Zorlu, A. (2006). Tüketim Sosyolojisi. Ankara: Cantekin Matbaası.

Zubomira, D. (2004). Environmental Education at Preschool. International Research in Geographical and Environmental Education, 13 (2), 258-263. 